\title{
Thermal and OXYGen conditions Of Lake Charzykowskie IN the Years 2014-2016
}

\author{
Warunki termiczno-tlenowe Jeziora Charzykowskiego w latach 2014-2016
}

\author{
КИСЛОРОДНО-ТЕРМИЧЕСКИЕ УСЛОВИЯ ОЗЕРА ХАЖИКОВСКОГО В 2014-2016 Г
}

\section{Thermische und Sauerstoffbedingungen des Charzykowskie Sees in den Jahren 2014-2016}

\section{Condiciones térmicas y de OXígeno del lago Charzykowskie en los años 2014-2016}

\author{
Jerzy K. Garbacz, Jacek Cieściński, Jerzy Ciechalski, Ryszard Dąbkowski, Jolanta Cichowska \\ University of Technology and Life Sciences in Bydgoszcz, Faculty of Civil Engineering; Architecture and Environmental Engineering, Department of Eco- \\ Engineering and Environmental Physical Chemistry \\ Uniwersytet Technologiczno-Przyrodniczy w Bydgoszczy, Wydział Budownictwa, Architektury i Inżynierii Środowiska, Katedra Ekoinżynierii i Fizykochemii \\ Środowiska
}

\section{STRESZCZENIA / ABSTRACTS}

This paper presents an analysis of thermal and oxygen conditions of the Charzykowskie Lake in the years 2014-2016 in the period from May to August. The measurements were carried out once a month, at points representing three different basins in the lake, and the temperatures and oxygen content dissolved in the water were recorded every $1 \mathrm{~m}$ from the surface to the bottom at the deepest point of each basin. The changes in temperatures and content of dissolved oxygen were analysed in each of the representative measurement points for particular parts of the lake. It has been shown that the deficit of oxygen dissolved in the bottom layers of the water starts occurring by the beginning of the summer stagnation period, whereas at its peak (August) the anaerobic zone includes hypolimnion and part of the metalimnion. The hypothesis that the thickness of the thermal layers varies within the lake basin was confirmed. It was also shown that the oxygen content curve at representative points, in all years of research, evolves to the form of a clinograde at the peak of summer stagnation, where the concentration of dissolved oxygen decreases with the depth.

Keywords: water stratification, oxygen deficit, Lake Charzykowskie.

W pracy przedstawiono analizę warunków termiczno-tlenowych Jeziora Charzykowskiego w latach 2014-2016 w okresie od maja do sierpnia. Pomiary prowadzono raz w miesiacu, w punktach reprezentujacych trzy odmienne baseny w misie badanego jeziora. Wyniki pomiaru temperatury i zawartości tlenu rozpuszczonego w wodzie rejestrowano co $1 \mathrm{~m}$ od powierzchni do dna w najgłębszym miejscu każdego basenu. Poddano analizie zmiany temperatury i zawartości tlenu rozpuszczonego w każdym z reprezentatywnych punktów pomiarowych dla poszczególnych plos jeziora. Wykazano, że deficyt tlenu rozpuszczonego w wodzie warstw naddennych występuje już na początku okresu stagnacji letniej, a w jego szczycie (sierpień) strefa beztlenowa obejmuje hypolimnion i część metalimnionu. Potwierdzono hipotezę zakładającą, że miąższość warstw termicznych jest zróżnicowana w obrębie misy jeziornej. Wykazano także, że krzywa zawartości tlenu w punktach reprezentatywnych, we wszystkich latach w których prowadzono badania, ewoluuje do postaci klinogrady w szczycie stagnacji letniej, gdzie stężenie tlenu rozpuszczonego maleje wraz z głębokością.

Słowa kluczowe: stratyfikacja wód, deficyt tlenu, Jezioro Charzykowskie.

В работе представлен анализ кислородно-термических условий озера Хажиковского в 2014-2016 гг в период с мая по август. Замеры проводились один раз в месяц в точках, представляющих три различных бассейна в ложе изучаемого озера. Результаты замера температуры и содержания кислорода, растворенного в воде, регистрировались каждый метр от поверхности воды до дна в самых глубоких местах бассейна. Проведен анализ изменений температуры и содержания растворенного кислорода в каждой из представленных точек замера для отдельных участков озера. Выявлено, что дефицит растворенного кислорода в воде придонных слоев появляется уже в начале периода летней стагнации, а на его пике (август) безкислородная зона охватывает гиполимнион и часть металимниона. Подтверждена гипотеза о том, что толщина термических слоев дифференцируется в пределах озерного ложа. Выявлено также, что кривая содержания кислорода в репрезентативных точках во все годы, когда проводились исследования, эволюционирует до формы прогиба на пике летней стагнации, где концентрация растворенного кислорода снижается с глубиной.

Ключевые слова: стратификация вод, дефицит кислорода, озеро Хажиковское

ARTICLE INFO

PolHypRes 201 Vol. 62 Issue 1 pp. 85 - 96

ISSN: $1734-7009$ elSSN: 2084-0535

DOI: 10.2478/phr-2018-0007

Pages: 12, figures: 4 , tables: 1

page www of the periodical: www.phr.net.pl

Publisher

Polish Hyperbaric Medicine and Technology Society
Typ artykułu: oryginalny

Original article

Termin nadesłania: $14.12 .2017 \mathrm{r}$.

Termin zatwierdzenia do druku: 03.02.2018 r. 
Der Beitrag stellt die Analyse der thermischen Bedingungen sowie die Sauerstoffbedingungen des Sees Charzykowskie in den Jahren 2014-2016 in der Zeit von Mai bis August vor. Die Messungen wurden einmal monatlich an Punkten vorgenommen, die drei verschiedene Becken des untersuchten Seegebietes präsentieren. Die Ergebnisse der Messungen von Temperatur und Sauerstoffgehalt, wurden in Abständen von $1 \mathrm{~m}$ von der Wasseroberfläche bis hin zum Boden - an der jeweils tiefsten Stelle der Becken - gemessen. Die Temperaturänderung und der Gehalt an gelöstem Sauerstoff wurden in jedem der repräsentativen Messpunkte für einzelne Seegrundflächen analysiert. Es zeigte sich, dass das Defizit an Sauerstoff im Wasser der dem Boden übergelagerten Schichten bereits am Anfang der Stagnationsperiode im Sommer auftritt; in der Spitzenzeit (August) umfasst die sauerstoffarme Zone das Hypolimnion und einen Teil des Metalimnions. Es bestätigte sich die

Hypothese, dass die Dicke der thermischen Schichten innerhalb des Seebeckens variiert. Weiter wurde aufgezeigt, dass die Kurve des Sauerstoffgehalts an repräsentativen Punkten in sämtlichen Untersuchungsjahren auf dem Höhepunkt der Sommerstagnation, wenn die Konzentration von gelöstem Sauerstoff mit der Tiefe abnimmt, die Form eines Klinograds annimmt.

Schlüsselwörter: Wasserstratifikation, Sauerstoffdefizit, Charzykowskie-See.

El documento presenta un análisis de las condiciones térmicas y de oxígeno presentes en el lago Charzykowskie entre los años $2014-2016$ en el período comprendido entre mayo y agosto. Las mediciones se realizaron una vez al mes en puntos que representaban tres piscinas diferentes en la cuenca del lago investigado. Los resultados de las mediciones de la temperatura y del contenido de oxígeno disuelto en el agua fueron registrados cada $1 \mathrm{~m}$, desde la superficie hasta el fondo, en el punto más profundo de cada piscina. Se analizaron los cambios de temperatura y el contenido de oxígeno disuelto en cada uno de los puntos de medición representativos de cada parcela de lago. Se ha demostrado que la deficiencia de oxígeno disuelto en el agua de las capas superficiales se produce ya al principio del período de estancamiento estival, y en su punto álgido (agosto) la zona anaeróbica incluye el hipolimnion y parte del metalimnión. Se ha confirmado la hipótesis de que el espesor de las capas térmicas varía dentro de la cuenca del lago. También se ha demostrado que la curva de oxígeno en los puntos representativos, en todos los años de investigación, evoluciona hacia un clinograma en el pico del estancamiento estival, donde la concentración de oxígeno disuelto disminuye con la profundidad.

Palabras clave: estratificación de las aguas, déficit de oxígeno, lago Charzykowskie. 


\section{WSTĘP}

Warunki

termiczno-tlenowe

obok przezroczystości, zasolenia, zawartości pierwiastków biogennych należą do podstawowych wskaźników charakteryzujących warunki abiotyczne w ocenie i klasyfikacji ekosystemów jeziornych [1,2,3,4,5,6,7]. W strefie klimatu umiarkowanego, w okresie letnim, między względnie ciepłą dobrze natlenioną i prześwietloną warstwą epilimnionu i chłodnym dysfotycznym hipolimnionem, wykształca się przejściowa warstwa skoku termicznego.

Różnice gęstości między chłodną wodą zalegającą od okresu wiosennego przy dnie, a ciepłą warstwą powierzchniową utrwalają rozwarstwienie, aż do ponownego wymieszania jesienią wskutek schłodzenia warstw powierzchniowych $[8,9,10]$. Pojawianie się termicznych warstw stratyfikacyjnych jest zjawiskiem cyklicznym i związane jest $\mathrm{z}$ wymianą ciepła między jeziorem i jego otoczeniem $\mathrm{w}$ różnych porach roku. Jeziora stymulują $\mathrm{w}$ ten sposób przepływ energii i obieg materii w ekosystemach śródlądowych [11]. Lustro wody jest naturalną granicą wymiany energii i masy między zbiornikiem i jego otoczeniem, strefą absorpcji promieniowania słonecznego mającej podstawowe znaczenie dla bilansu cieplnego całego zbiornika [12].

Mieszanie warstw powierzchniowych poza wymianą energii cieplnej dostarcza tlen, który rozpuszcza się w wodzie tym lepiej, im niższa jest jej temperatura. Równie ważnym źródłem tlenu w wodzie, jest proces fotosyntezy. W sprzyjających warunkach może pojawić się lokalnie przesycenie wody tlenem $\mathrm{w}$ warstwach powierzchniowych akwenu, co najczęściej interpretowane jest jako skutek przeżyźnienia ekosystemu. Wyznaczenie $\mathrm{w}$ tym okresie profili termiczno-tlenowych poza ustaleniem zasięgu i miąższości warstw stratyfikacyjnych, ułatwia zidentyfikowanie stref; trofogenicznej i trofolitycznej w ekosystemie [9,17].

Następstwem przeżyźnienia jest „produkcja” nadmiernej biomasy fitoplanktonu, który ostatecznie w znacznej części sedymentuje w postaci obumarłych szczątków w kierunku dna zbiornika. Rozkład związków organicznych zachodzi w całym ekosystemie, $\mathrm{z}$ tą jednak różnicą, że w hipolimnionie i części metalimnionu ubytki tlenu nie są uzupełniane od początku do końca stagnacji letniej w jeziorach strefy klimatu umiarkowanego.

W konsekwencji stan ten przyczynia się do powstania deficytów tlenowych, a nawet jego całkowitego wyczerpania $\mathrm{w}$ tych warstwach. Ponowne dotlenienie całej masy wody zdarzyć się może w efekcie jej mieszania i kontaktu z atmosferą po wyrównaniu temperatury i gęstości wody od powierzchni do dna. Poza autochtoniczną materią organiczną, której źródłem w ekosystemie są żywe organizmy i ich szczątki, zbiorniki wodne zasilane sa materia allochtoniczna $\mathrm{z}$ obszaru zlewni.

Już sama obecność (bytowanie) ludzi w zlewni, generuje znaczący ładunek zanieczyszczeń organicznych. W obliczeniach dotyczących oczyszczania ścieków komunalnych przyjmuje się, że przeliczeniowy statystyczny mieszkaniec gospodarstwa domowego „produkuje” w ciągu doby taki ładunek substancji organicznych, którego biologiczny rozkład (BZT5) wymaga zużycia 60 gramów tlenu (art. 43. 1., prawo

\section{INTRODUCTION}

Thermal and oxygen conditions, in addition to the transparency, salinity, and content of biogenic elements, are among the basic indicators characterising abiotic conditions in the assessment and classification of lake ecosystems $[1,2,3,4,5,6,7]$. During the summer months, a transient layer of a thermal jump develops in the temperate climate zone located between the relatively warm, well-oxygenated and well-exposed epilimnion layer, and the cold dysphotic hypolimnion.

Density differences between the cool water that accumulates from the spring period at the bottom of the lake, and the warm surface layer preserve the stratification until re-mixing in autumn due to the cooling of surface layers $[8,9,10]$. The occurrence of thermal stratification layers is a cyclical phenomenon and is associated with the heat exchange between the lake and its surroundings in different seasons of the year. This way, lakes stimulate the energy flow and the circulation of matter in inland ecosystems [11]. The water level is a natural limit of energy and mass exchange between the reservoir and its surroundings, the zone of absorption of solar radiation, which is fundamental for the thermal balance of the entire reservoir [12].

The mixing of surface layers, apart from enabling the exchange of thermal energy, provides oxygen, which dissolves in water the better, the lower its temperature is. An equally important source of oxygen in water is the photosynthesis process. In favourable conditions a local saturation of water with oxygen may occur in the surface layers of the body of water, which is most often interpreted as a result of the ecosystem's eutrophication. The determination of thermal-oxygen profiles in this period, apart from determining the extent and thickness of stratification layers, makes it easier to identify the trophogenic and trophic zones in the ecosystem $[9,17]$.

The consequence of eutrophication is the "production" of excessive phytoplankton biomass, which ultimately sediments in the form of dead remains at the bottom of the reservoir. Decomposition of organic compounds occurs in the whole ecosystem, but it is noteworthy that in the hypolimnion and part of the metalimnion, oxygen losses are not replenished in the lake's temperate climate zone throughout the period of the summer stagnation.

As a consequence, this condition contributes to the occurrence of oxygen deficits and even its complete exhaustion in these layers. Re-oxygenation of the whole mass of water may happen as a result of its mixing, and contact, with the atmosphere following the equalisation of the temperature and density between the water from the surface of the lake, and that of the bottom. In addition to the indigenous organic matter, whose source in the ecosystem are living organisms and their remains, water reservoirs are fed with allochthonic matter from the reception basin area.

Even the presence (living) of people in the reception basin area, generates a significant load of organic pollutants. In the calculations performed in relation to urban wastewater treatment, it is assumed that within a day, the statistical household inhabitant "produces" such a load of organic substances, whose biological breakdown (BOD5) requires consumption of 60 
wodne).

Z tych względów wydaje się oczywiste, że jeziora stratyfikowane nie powinny być bezpośrednim odbiornikiem nieoczyszczonych ścieków komunalnobytowych. Jednak Jezioro Charzykowskie, położone na granicy Parku Narodowego „Bory Tucholskie” za pośrednictwem małej rzeki o nazwie „Struga Jarcewska”, do 1990 roku, zasilane było niemczyszczo-nymi ściekami komunalnymi z czterdziestotysięcznego miasta Chojnice.

Pomimo znacznego zmniejszenia ładunku zanieczyszczeń jakie dopływają do jeziora od czasu oddania do użytku oczyszczalni ścieków, struga ta w dalszym ciągu należy do głównych źródeł zanieczyszczeń pochodzenia antropogenicznego. Skutkiem wieloletniego użyźniania jeziora były nie tylko zmiany w strukturze biocenotycznej $[18,19,20,21]$, ale także pogłębiające się deficyty a w konsekwencji brak tlenu rozpuszczonego $\mathrm{w}$ stagnujących warstwach wody $[22,23,24,25]$.

W ostatnich latach jezioro zostało objęte również programem EUKALKES dla Europy Środkowej w celu wsparcia zrównoważonego zarządzania jeziorem oraz oceny czystości [26].

Celem badań była analiza zmian temperatury i natlenienia wody w miejscach największych przegłębień, trzech głównych basenów Jeziora Charzykowskiego w okresie po przemieszaniu wiosennym do szczytu stagnacji letniej.

Realizację powyższego celu podporządkowano następującej hipotezie badawczej:

1. W każdym punkcie pomiarowym w całym okresie badawczym obserwuje się statystycznie istotną korelację pomiędzy temperaturą a zawartością tlenu rozpuszczonego $\mathrm{w}$ wodzie.

2. Istnieje zróżnicowanie miąższości warstw stratyfikacyjnych i zawartości tlenu rozpuszczonego $\mathrm{w}$ głównych basenach Jeziora Charzykowskiego, odmiennych pod względem cech morfometrycznych, hydrograficznych i zlewniowych.

\section{OGÓLNA CHARAKTERYSTYKA ZLEWNI JEZIORA CHARZYKOWSKIEGO}

Jezioro Charzykowskie jest największym naturalnym zbiornikiem wodnym w zlewni rzeki Brdy, o czym świadczą wartości następujących podstawowych parametrów morfometrycznych:

- powierzchnia lustra wody- $1363,8 \mathrm{ha}$,

- objętość wody w jeziorze- 134533,2 tys. $\mathrm{m}^{3}$,

- maksymalna długość zbiornika- $10025 \mathrm{~m}$,

- maksymalna szerokość zbiornika- 2425 m,

- całkowita długość linii brzegowej- 31925 m

- maksymalna głębokość zbiornika- 30,5 m,

- $\quad$ średnia głębokość zbiornika- 9,8 m.

Jezioro wypełnia południową część rynny glacjalnej o przebiegu NS od miejscowości Charzykowy do miejscowości Małe Swornegacie, natomiast najszerszym miejscem jest środkowa część zbiornika (okolice Funki). Misa zbiornika składa się z trzech wyraźnie oddzielonych części, nazwanych odpowiednio: misą południową, środkową i północną. W obszarze progów istnieją dwie niewielkie wyspy. Najgłębszą jest misa południowa, i tu około 200 m od półwyspu nazywanego "Górą Zamkową", znajduje się maksymalna głębokość jeziora.

Nieco płytsza jest środkowa część jeziora, która grams of oxygen (Article 43.1, water law).

For these reasons, it seems obvious that stratified lakes should not be a direct receiver of untreated urban wastewater. However, Lake Charzykowskie, located on the border of the "Tucholskie Forests" National Park, was until 1990 the recipient of the untreated municipal wastewater of the forty thousand inhabitants of the city of Chojnice.

Despite the significant reduction in the load of pollutants that have been flowing into the lake since the sewage treatment plant was put into operation, the "Struga Jarcewska" river which carries the waste from Chojnice still remains one of the main sources of anthropogenic pollution. The upshot of the many years of eutrophication of the lake were not only changes in the biocenotic structure $[18,19,20,21]$, but also the deepening deficits and, consequently, lack of dissolved oxygen in stagnant layers of water $[22,23,24,25]$.

In recent years, the lake has also been covered by the EUKALKES programme for Central Europe to support sustainable lake management and cleanliness assessment [26].

The aim of the research was to analyse changes in temperature and oxygenation of water in the largest overdeepenings of the three main basins of Lake Charzykowskie, the study being carried out in the period between the spring mixing and the peak of the summer stagnation. The implementation of the above goal was governed by the following research hypotheses:

1. At each measuring point throughout the entire test period, a statistically significant correlation between the temperature and the dissolved oxygen content in the water is observed.

2. There is variation in the thickness of the stratification layers and the dissolved oxygen content in the main basin of Lake Charzykowskie, this being different in terms of morphometric, hydrographic and receptive features.

\section{GENERAL CHARACTERISATION OF THE RECEPTION BASIN OF LAKE CHARZYKOWSKIE}

Lake Charzykowskie is the largest natural water reservoir in the Brda river basin as evidenced by the values of the following basic morphometric parameters:

- $\quad$ water surface - $1363.8 \mathrm{ha}$,

- water volume in the lake - 134533.2 thous. m3,

- maximum length of reservoir $-10025 \mathrm{~m}$,

- maximum width of reservoir - $2425 \mathrm{~m}$,

- total length of the shoreline - $31925 \mathrm{~m}$,

- maximum depth of the reservoir $-30.5 \mathrm{~m}$,

- $\quad$ average depth of the reservoir $-9.8 \mathrm{~m}$.

The lake fills the southern part of the glacial trough on a NS course from the village of Charzykowy to Małe Swornegacie, the widest part being the central part of the reservoir (in the vicinity of Funka village). The reservoir consists of three clearly separated parts, respectively named: southern, central and northern basin. In the area of ledges there are two small islands. The deepest part of the lake is found in the southern basin about $200 \mathrm{~m}$ from the peninsula called "Góra Zamkowa" [Castle Hill].

The central part of the lake is slightly shallower and has two deeper parts, each with the depth of $25 \mathrm{~m}$. The northern part of the lake has a different character 
ma dwa głęboczki, każdy o głębokości 25 m. Północna część jeziora ma odmienny charakter niż południowa i środkowa, gdyż jest znacznie płytsza (maksymalna głębokość: ok. $12 \mathrm{~m}$ ), charakteryzuje się płaskimi i niskimi brzegami, a płycizna przybrzeżna łączy się bezpośrednio $\mathrm{z}$ dnem. Przez to ploso przepływa rzeka Brda, która silnie oddziałuje na tę część jeziora.

Pod względem administracyjnym jezioro położone jest w województwie pomorskim. Jest to obszar należący do makroregionu Pojezierza Południowopomorskiego, a dokładniej mezoregoinu Równina Charzykowska i Bory Tucholskie. Zlewnia bezpośrednia, i częściowo czterech głównych dopływów zasilających ten zbiornik, położona jest w obrębie Zaborskiego Parku Krajobrazowego, a od północnego wschodu jezioro graniczy z Parkiem Narodowym „Bory Tucholskie".

W obszarze zlewni jeziora dominują krajobrazy młodoglacjalne, charakteryzujące się występowaniem mniej lub bardziej głębokich jezior, powstałych w wyniku stopienia brył lodu u schyłku epoki lodowcowej na terenie istniejącej tutaj pierwotnie równiny akumulacyjnej. Erozyjna działalność wód glacjalnych najlepiej wykształciła rynny Strugi Siedmiu Jezior i samego Jeziora Charzykowskiego. $\mathrm{Na}$ ewolucję i urozmaicenie tego krajobrazu miały i mają wpływ również liczne rzeki, które zasilają jeziora. Dobrym tego przykładem może być Struga Siedmiu Jezior, której zlewnia determinuje krajobraz wspomnianego Parku Narodowego [28].

Całkowita powierzchnia zlewni Jeziora Charzykowskiego wynosi $913,5 \mathrm{~km}^{2}$, z czego na zlewnię Brdy przypada aż $667,2 \mathrm{~km}^{2}$, natomiast pozostałe 246,3 $\mathrm{km}^{2}$ to:

- zlewnia Czerwonej Strugi $78,8 \mathrm{~km}^{2}$,

- zlewnia Strugi Jarcewskiej $52,0 \mathrm{~km}^{2}$,

- zlewnia Strugi Siedmiu Jezior 54,6 km²,

- obszar spływu bezpośredniego $60,9 \mathrm{~km}^{2}$.

Rzeka Brda jest największym dopływem, a za jej początek uznaje się Jezioro Smołowe na wysokości 181 m. n.p.m. Rzeka uchodzi do Jeziora Charzykowskiego na wysokości 120 m. n.p.m. z niewielkim spadkiem, a swój bieg kończy kilka kilometrów na wschód od Bydgoszczy, gdzie wpływa do Wisły na poziomie 31 m. n.p.m. Charakterystyczną cechą tej rzeki jest stosunkowo duża liczba zbiorników wodnych, przez które przepływa, z wyraźnym wyodrębnieniem górnego biegu, gdzie jej wody zasilają dziesięć, różnej wielkości, naturalnych jezior oraz dolnego odcinka, w którym wybudowano w okresie powojennym kaskadę jezior zaporowych różnej wielkości. Największym jeziorem naturalnym, przez które przepływa Brda, jest właśnie Jezioro Charzykowskie.

Struga Czerwona, znana także pod nazwą Kopernica, jest niewielkim ciekiem naturalnym o długości $16,9 \mathrm{~km}$, przepływającym w początkowym swym biegu przez obszary użytkowane rolniczo, a potem przez obszary leśne. Początek rzeki stanowi jezioro Kłodzko Małe na wysokości 152 m. n.p.m. a uchodzi do Jeziora Charzykowskiego na wysokości 120 m. n.p.m.

Struga Siedmiu Jezior, o długości $13 \mathrm{~km}$, wypływa z jeziora Ostrowite i przepływa przez teren Parku Narodowego "Bory Tucholskie" przez następujące jeziora: Zielone, Jeleń, Bełczak, Płęsno, Skrzynka i Mielnica. Zlewnią rzeki jest praktycznie w całości zalesiony obszar Parku Narodowego.

Struga Jarcewska jest jego lewobrzeżnym dopływem południowej części Jeziora Charzykowskiego. than the southern and central ones, as it is much shallower (maximum depth: approx. $12 \mathrm{~m}$ ), and characterised by flat and low banks, and the shoal at the shore is connected directly to the bottom. The Brda river flows through it, which strongly affects this part of the lake.

In administrative terms, the lake is located in the Pomeranian province. It is an area belonging to the macroregion of the South-Pomeranian Lake District, more precisely the of the Charzykowska Plain and Tucholskie Forests. The direct reception basin, and partly the catchment of the four main tributaries feeding this reservoir, is located within the Zaborski Landscape Park, and from the north-east the lake borders with the Tucholskie Forests National Park.

In the area of the lake's catchment, the landscape is mainly of a young glacial type, characterised by the existence of lakes of varying deepness formed as a result of melting ice chunks at the end of the ice age in the area of a former accumulation plain. The erosive activity of glacial waters was best developed by the trough of Struga Siedmiu Jezior [the Seven Lakes Stream] and Lake Charzykowskie itself. Numerous rivers that feed the lakes had and still have an impact on the diversification of this landscape. A good example of this is Struga Siedmiu Jezior [the Seven Lakes Stream], whose reception basin determines the landscape of the aforementioned National Park [28].

Total catchment area of Lake Charzykowskie is $913.5 \mathrm{~km}^{2}$, with the Brda catchment covering as much as $667.2 \mathrm{~km}^{2}$, and the remaining area of $246.3 \mathrm{~km}^{2}$ being divided among:

- $\quad$ the catchment of Czerwona Struga $78.8 \mathrm{~km}^{2}$,

- the catchment of Struga Jarcewska $52.0 \mathrm{~km}^{2}$,

- the catchment of Struga Siedmiu Jezior $54.6 \mathrm{~km}^{2}$,

- $\quad$ direct runoff area $60.9 \mathrm{~km}^{2}$.

The Brda River is the largest tributary, and its beginning is considered to be Lake Smołowe at an altitude of $181 \mathrm{~m}$ above sea level. The river flows into Lake Charzykowskie at $120 \mathrm{~m}$ above sea level with a slight slope, and ends its course several kilometres east of Bydgoszcz where it flows into the Vistula at just $31 \mathrm{~m}$ above sea level. A characteristic feature of this river is the relatively large number of water reservoirs through which it flows, with a distinct separation of the upper course, where its waters feed ten natural lakes of varying size and the lower section in which a cascade of dam lakes of various sizes was built in the post-war period. The largest natural lake through which Brda flows is Lake Charzykowskie.

Struga Czerwona, also known as Kopernica, is a small natural watercourse with a length of $16.9 \mathrm{~km}$, flowing in its initial course through areas used for agriculture, and next through forested areas. The beginning of the river is Lake Kłodzko Małe at an altitude of $152 \mathrm{~m}$ above sea level which flows into Lake Charzykowskie at an altitude of $120 \mathrm{~m}$ above sea level.

Struga Siedmiu Jezior with a length of $13 \mathrm{~km}$ flows out of Lake Ostrowite and through the territory of the "Tucholskie Forests" National Park and the following lakes: Zielone, Jeleń, Bełczak, Płęsno, Skrzynka and Mielnica. The river basin is the practically completely forested area of the National Park.

Struga Jarcewska is its left-bank tributary of the southern part of Charzykowskie Lake. It drains the north-eastern part of the Krajeńska Upland, and at the same time it is a receiver of industrial and communal 
Odwadnia północno-wschodnią część Wysoczyzny Krajeńskiej, a jednocześnie jest odbiornikiem ścieków przemysłowych i komunalnych z miasta Chojnic. Jej źródła znajdują się na południe od Chojnic, na wysokości 150 m. n.p.m. Przepływa, częściowo zakryta, przez miasto i odwadnia mokradła na odcinku między miejscowościami Igły i Jarcewo. Tereny leśne stanowią mniej niż $25 \%$ całości obszaru zlewni. Na wysokości 120,3 m. n.p.m., w okolicy osady Stary Młyn, wpada do Jeziora Charzykowskiego. Długość Strugi Jarcewskiej wynosi $12 \mathrm{~km}$.

\section{MATERIAE I METODY}

Pomiary temperatury i zawartości tlenu rozpuszczonego wykonano $\mathrm{w}$ miejscu największego przegłębienia $\mathrm{w}$ trzech punktach reprezentatywnych dla każdego z basenów jeziora. Badania prowadzone były w latach 2014, 2015 i 2016 od maja do sierpnia jednorazowo $\mathrm{w}$ każdym $\mathrm{z}$ tych miesięcy. Sondowania wykonano w ciągu jednego dnia w celu odzwierciedlenia warunków termiczno-tlenowych w obrębie całego jeziora przy praktycznie niezmiennych warunkach meteorologicznych. Punkty pomiarowe zlokalizowano na podstawie planów batymetrycznych Instytutu Rybactwa Śródlądowego w Olsztynie i przy pomocy GPSMap 60 CSx firmy Garmin. Dokładną głębokość dla danego punktu wyznaczono echosondą HUMMINBIRD MATRIX27.

Pomiarów temperatury oraz zawartości tlenu $\mathrm{w}$ wyznaczonych punktach pomiarowych dokonano z łodzi przy użyciu sondy tlenowej typu OXI 196 WTW w przekroju pionowym co 1 metr od lustra wody do dna. W każdym punkcie pomiarowym przekroju odnotowano temperaturę $\mathrm{w}{ }^{\circ} \mathrm{C}$, zawartość tlenu rozpuszczonego $\mathrm{w} \mathrm{mg} / \mathrm{dm}^{3}$ oraz procentowe nasycenie wody tlenem.

Uzyskane wyniki zaprezentowano $\mathrm{w}$ postaci wykresów zależności temperatury i zawartości tlenu rozpuszczonego od głębokości. Wykresy te ilustrują wyżej podane zależności dla każdego z trzech wyznaczonych punktów reprezentatywnych jeziora, w miesiącach od maja do sierpnia w latach 2014, 2015 i 2016.

Lokalizację punktów pomiarowych przedstawiono na Rysunku 1. waste water from the city of Chojnice. Its sources are located south of Chojnice, at an altitude of $150 \mathrm{~m}$ above sea level. It flows, partially covered, through the city and drains the wetlands in the section between the villages of Igła and Jarcewo. Forested areas constitute less than 25\% of the entire catchment area. At an altitude of $120.3 \mathrm{~m}$ above sea level, near the village of Stary Młyn, it flows into Lake Charzykowskie. The length of the Jarcewska Stream is $12 \mathrm{~km}$.

\section{MATERIAL AND METHODS}

Measurements of temperature and dissolved oxygen content were made at the place of the largest trim in three points representative of each lake basin. The research was conducted in 2014, 2015 and 2016 from May to August - once in each of these months. Measurements of both the water temperature and oxygen content were collected on the same day in order to reflect the thermal-oxygen conditions within the entire lake in practically unchanged meteorological conditions. Measuring points were defined on the basis of bathymetric plans of the Inland Fisheries Institute in Olsztyn and Garmin's GPSMap $60 \mathrm{CSx}$. The exact depth of a given point was determined with the HUMMINBIRD MATRIX27 echosounder.

Measurements of temperature and oxygen content at designated measurement points were made from a boat using the OXI 196 WTW oxygen probe in a vertical section every meter from the water surface to the bottom. At each measurement point of the section, the temperature was recorded in ${ }^{\circ} \mathrm{C}$, the dissolved oxygen content in $\mathrm{mg} / \mathrm{dm} 3$ and the percentage saturation of water with oxygen.

The obtained results were presented in the form of diagrams showing the dependence of temperature and dissolved oxygen content on depth. These charts illustrate the above-mentioned relationships for each of the three designated representative points of the lake, in the months from May to August in 2014, 2015 and 2016. The location of measurement points is shown in Figure 1. 


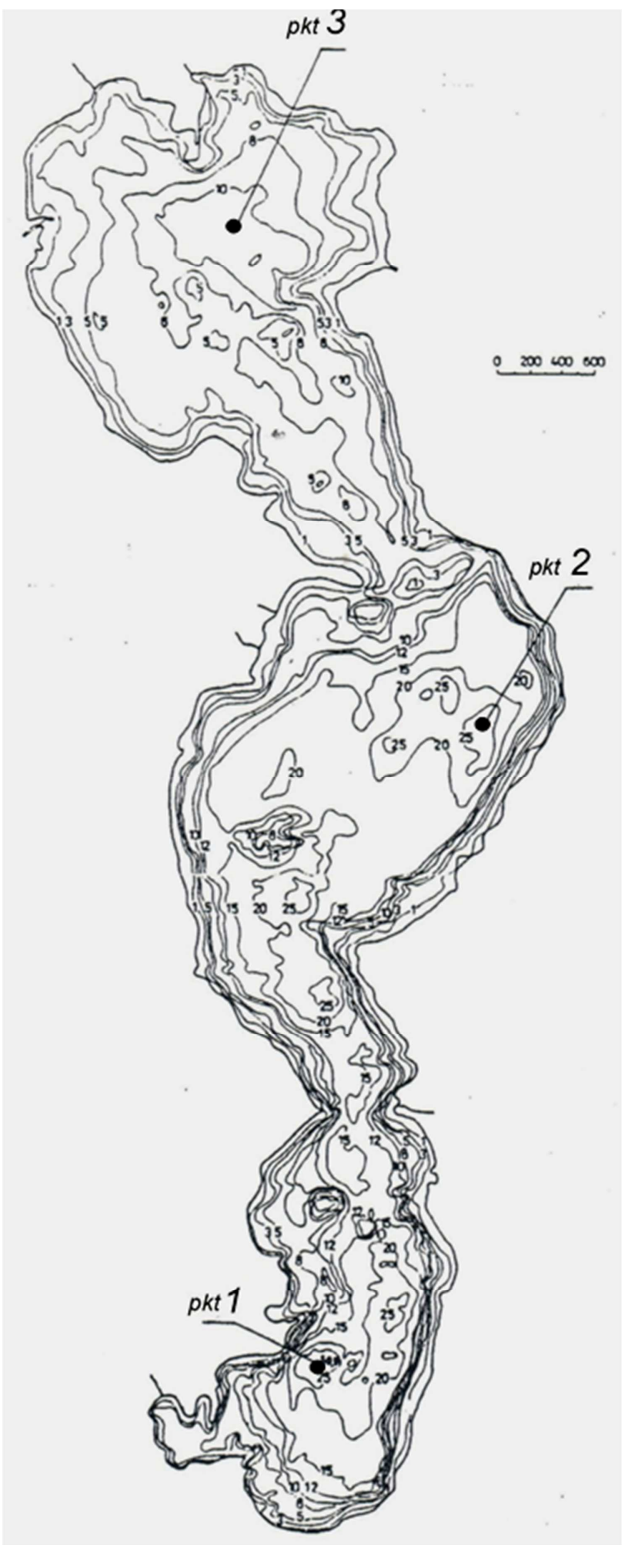

Fig.1. The location of measurement points.

Rys. 1. Lokalizacja punktów pomiarowych. 

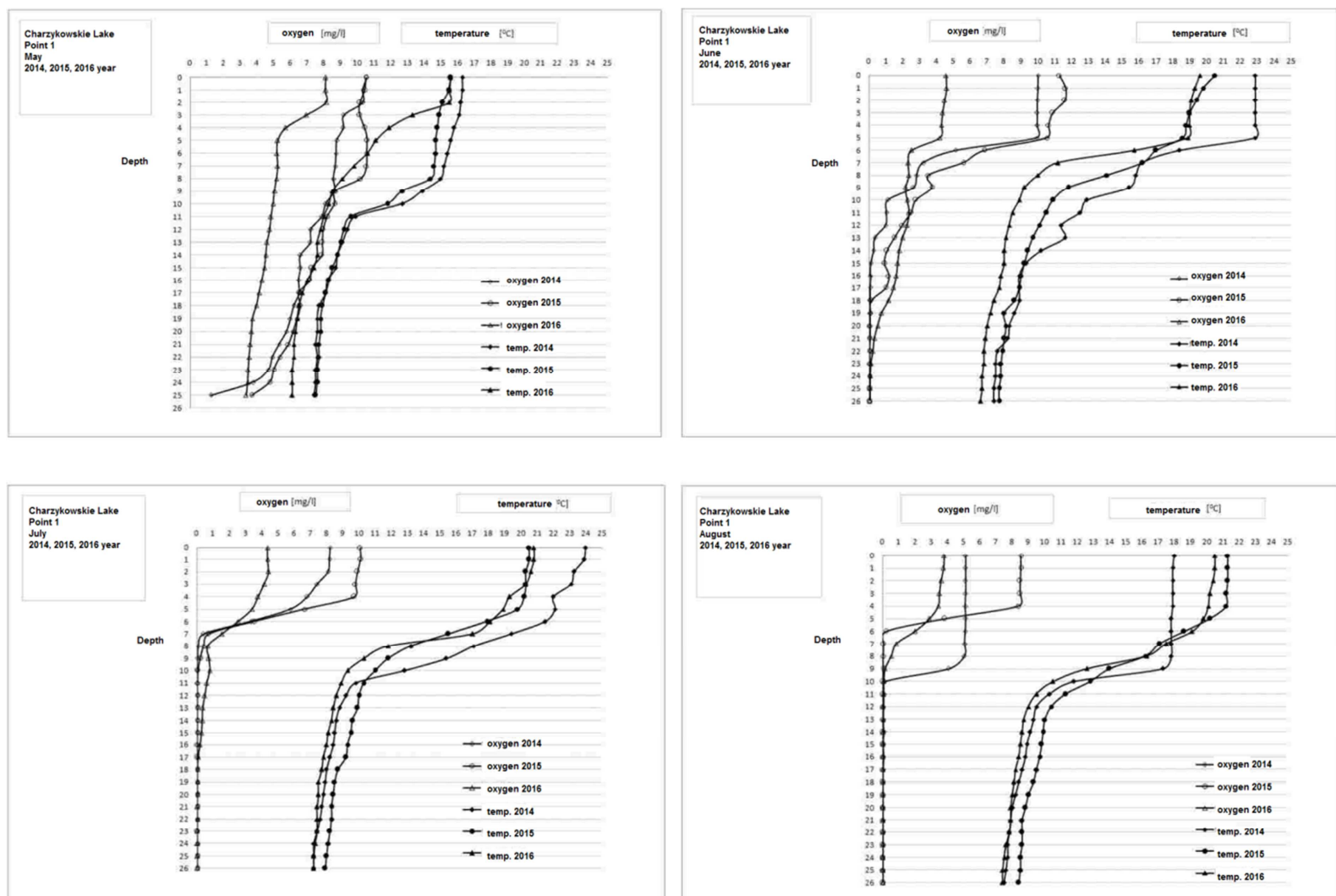

Fig. 2. The dependence of temperature and dissolved oxygen content on depth in May, June, July and August in the years $2014,2015,2016$ at the $1^{\text {st }}$ measurement point.

Rys. 2. Zależność temperatury i zawartości tlenu rozpuszczonego od głębokości miesiącach maj, czerwiec, lipiec i sierpień w latach $2014,2015,2016$ w punkcie pomiarowym 1 .
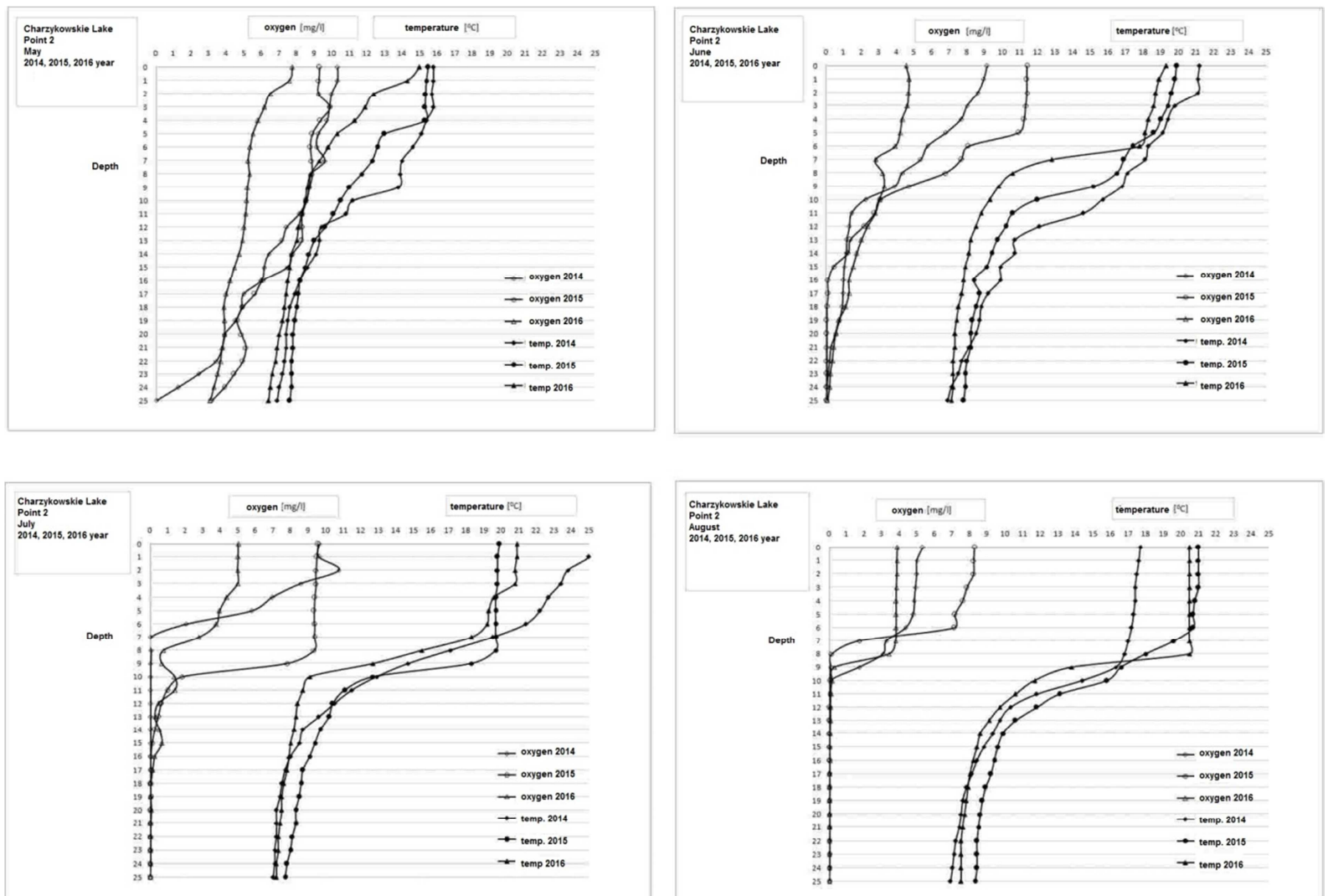

Fig. 3. The dependence of temperature and dissolved oxygen content on depth in May, June, July and August in the years $2014,2015,2016$ at the $2^{\text {nd }}$ measurement point.

Rys. 3 Zależność temperatury i zawartości tlenu rozpuszczonego od głębokości miesiącach maj, czerwiec, lipiec i sierpień w latach 2014 , 2015 , 2016 w punkcie pomiarowym 2 . 

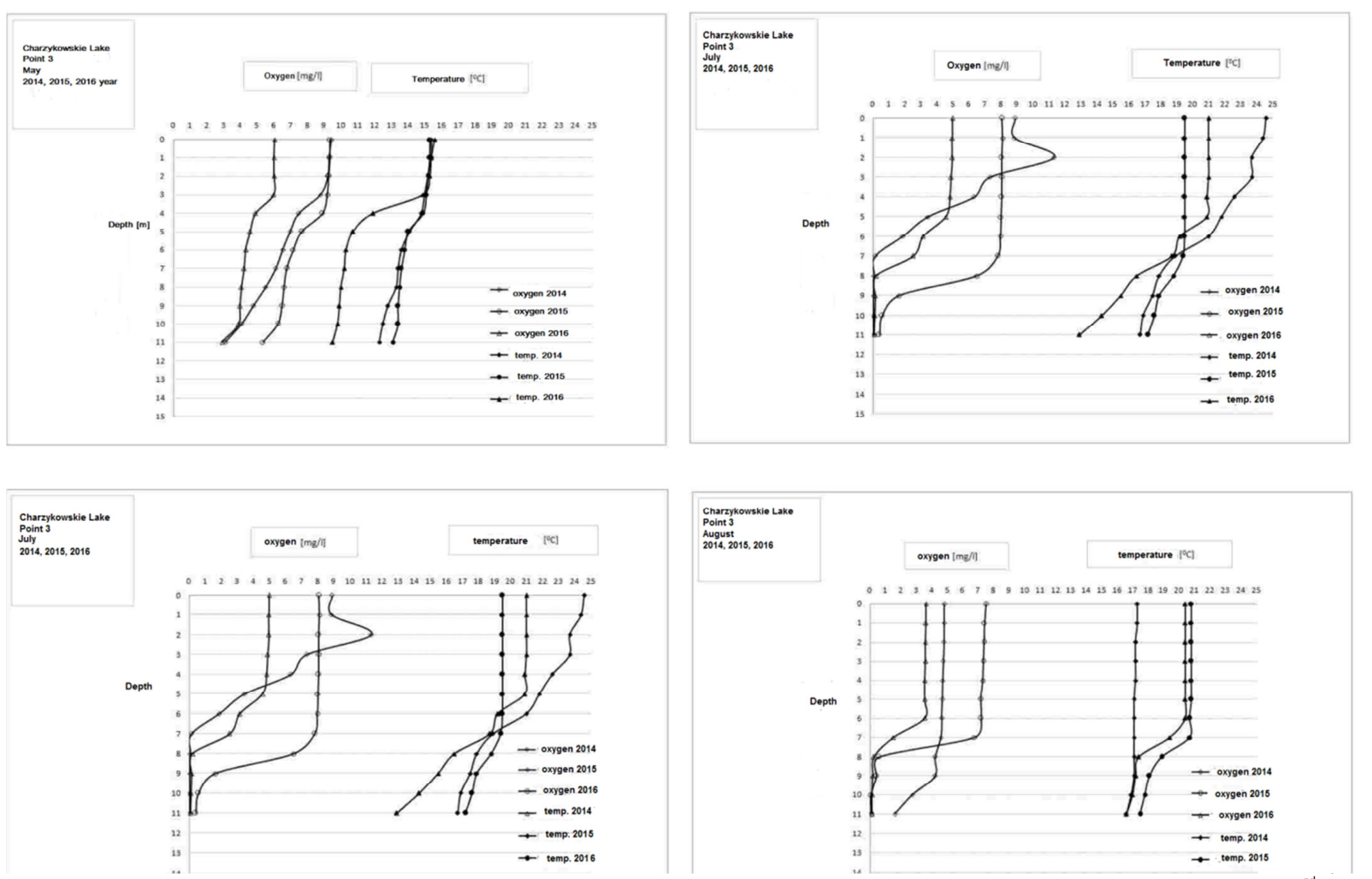

Fig. 4 The dependence of temperature and dissolved oxygen content on depth in May, June, July and August in the years 2014, 2015, 2016 at the $3^{\text {rd }}$ measurement point.

Rys. 4 Zależność temperatury i zawartości tlenu rozpuszczonego od głębokości miesiącach maj, czerwiec, lipiec i sierpień w latach 2014 , 2015 , 2016 w punkcie pomiarowym 3 .

\section{OMÓWIENIE WYNIKóW}

W celu weryfikacji punktu 1 hipotezy badawczej obliczono dla każdego punktu pomiarowego w każdym miesiącu badawczym każdego roku wartości współczynnika korelacji liniowej pomiędzy temperaturą i zawartością tlenu rozpuszczonego w wodzie. Rezultaty obliczeń zamieszczono $\mathrm{w}$ Tabeli 1 . Dla przyjętego w niniejszej pracy poziomu istotności 0,05 i ze względu na dwustronny charakter testu krytyczne wartości współczynnika korelacji wynoszą odpowiednio: 0,3809 dla punktu 1 (27 pomiarów), 0,3893 dla punktu 2 (26 pomiarów) oraz 0,5760 dla punktu 3 (12 pomiarów).

Na podstawie danych Tabeli 1 można stwierdzić, bez jakichkolwiek wyjątków, że wszystkie zamieszczone tam liczby przekraczają ze znacznym nadmiarem warunek minimum istotności statystycznej, przy czym spośród 36 wartości zaledwie 6 mieści się w przedziale $0,8-0,9$, natomiast pozostałe przekraczają 0,9 osiągając w czterech przypadkach praktycznie jedynkę. Uzyskany rezultat stanowi zatem silną przesłankę weryfikacji punktu 1 powyższej hipotezy badawczej.

W maju roku 2014, 2015 i 2016 w trzech punktach pomiarowych wartości temperatury i zawartość tlenu rozpuszczonego $\mathrm{w}$ wodzie wyraźnie wzrasta od warstw naddennych do powierzchnio-wych. Temperatura warstw powierzchniowych jeziora $w$ tym okresie osiągnęła już $15^{\circ} \mathrm{C}$, a na głębokościach poniżej $15 \mathrm{~m}$ nie przekroczyła $9^{\circ} \mathrm{C}$. W roku 2016 pomimo podobnej temperatury przy powierzchni, głębsze warstwy były znacznie chłodniejsze niż w latach 2014 i 2015. Podobna tendencja charakteryzowała warunki tlenowe.

\section{DISCUSSION OF RESULTS}

In order to verify point 1 of the research hypothesis, for each measuring point in each test month of each year, the values of the linear correlation coefficient between the temperature and the dissolved oxygen content in water were calculated. The results of the calculations are presented in Table 1 . For the significance level of 0.05 assumed in this study and due to the two-fold nature of the test, the critical values of the correlation coefficient are respectively: 0.3809 for point 1 (27 measurements), 0.3893 for point 2 (26 measurements) and 0.5760 for point 3 (12 measurements).

Based on the data in Table 1 it can be stated, without any exceptions, that all the numbers placed there exceed the minimum statistical significance condition with a significant excess, and out of 36 values only 6 fall within the range $0.8-0.9$, while the others exceed 0.9 , in four cases the result is 1 . The obtained result is therefore a strong premise for verification of point 1 of the above research hypothesis.

In May 2014, 2015 and 2016 at three measurement points the values of temperature and dissolved oxygen content in water clearly increases from the bottom to the surface layers. The temperature of the lake surface layers in this period already reached $15^{\circ} \mathrm{C}$, and at depths below $15 \mathrm{~m}$ did not exceed $9^{\circ} \mathrm{C}$. In 2016 , despite the similar temperature at the surface, the deeper layers were much cooler than in 2014 and 2015. A similar trend was characteristic of the aerobic conditions.

In points 1 and 2 (particularly in point 1 ) in May the thermal leap layer (metalimnion) is clearly formed. In 
W punktach 1 i 2 (zwłaszcza w punkcie 1) w maju wyraźnie kształtuje się już warstwa skoku termicznego (metalimnionu). W niemieszającej się już chłodnej warstwie jeziora (poniżej $9^{\circ} \mathrm{C}$ ) zawartość tlenu rozpuszczonego wyraźnie spada, a w roku 2014 poniżej $24 \mathrm{~m}$ występuje jego wyraźny deficyt. W czerwcu temperatura warstw powierzchniowych w obrębie całego jeziora wyraźnie wzrasta, zwłaszcza w roku 2014. the cool layer of the lake (below $9^{\circ} \mathrm{C}$ ) that no longer mixes, the dissolved oxygen content is clearly decreasing, and in 2014 below $24 \mathrm{~m}$ there is its clear deficit. In June, the temperature of surface layers within the entire lake is clearly increasing, particularly in 2014.

Values of the linear correlation coefficient in the system: temperature vs. dissolved oxygen content at particular measuring points of Lake Charzykowskie.

Wartości współczynnika korelacji liniowej w układzie: temperatura vs. zawartość tlenu rozpuszczonego, w poszczególnych punktach pomiarowych Jeziora Charzykowskiego.

\begin{tabular}{|c|c|c|c|}
\hline $\begin{array}{l}\text { year } \\
\text { point } \\
\end{array}$ & 2014 & 2015 & 2016 \\
\hline May & 0.8677 & 0.9331 & 0.9797 \\
\hline June & 0.9702 & 0.9854 & 0.9250 \\
\hline July & 0.8762 & 0.9287 & 0.9759 \\
\hline August & 0.9816 & 0.8358 & 0.9252 \\
\hline May & 0.9058 & 0.8357 & 0.9652 \\
\hline June & 0.9535 & 0.9907 & 0.9052 \\
\hline July & 0.8482 & 0.9922 & 0.9530 \\
\hline August & 0.9059 & 0.8466 & 0.9765 \\
\hline May & 0.9856 & 0.9893 & 0.9565 \\
\hline June & 0.9972 & 0.9049 & 0.9922 \\
\hline July & 0.9293 & 0.9902 & 0.9616 \\
\hline August & 0.9485 & 0.9800 & 0.9785 \\
\hline
\end{tabular}

W punkcie pomiarowym 1 (basen południowy) warstwa wody do głębokości $5 \mathrm{~m}$ osiągnęła temperaturę $23^{\circ} \mathrm{C}$. W latach 2015 i 2016 miąższość tej warstwy jest porównywalna, choć temperatura niższa. Poniżej tej warstwy temperatura $\mathrm{w}$ całym jeziorze $\mathrm{w}$ tym okresie gwałtownie spada, a na głębokości od 5 do 7 metrów następuje jej spadek o kilka stopni, nawet w znacznie płytszym (11 m) basenie północnym.

W chłodnej warstwie od głębokości $15 \mathrm{~m}$ do dna pogarszają się warunki tlenowe zwłaszcza w roku 2015, gdzie w czerwcu odnotowano jego brak od głębokości 18 m (punkty pomiarowe 1 i 2). Słabe nasycenie tlenem (poniżej $5 \mathrm{mg} / \mathrm{dm}^{3}$ ) charakteryzowało również warstwy powierzchniowe $\mathrm{w}$ obrębie całego jeziora $\mathrm{w}$ czerwcu, a także lipcu i sierpniu 2014 roku. W tych samych miesiącach w roku 2015 i 2016 w warstwie powierzchniowej, stężenie tlenu rozpuszczonego w wodzie miało wartość niemal dwukrotnie wyższą (w porównaniu do roku 2014).

Profile termiczne wykonane na podstawie pomiarów wykonanych w lipcu 2015 i 2016 roku mają już typowy kształt dla okresu stagnacji letniej jezior strefy klimatu umiarkowanego. Strefa skoku termicznego oddziela względnie ciepły epilimnion (około $23^{\circ} \mathrm{C}$ ) o miąższości ponad 8 metrów (punkt 2) od hypolimnionu, który w roku 2016 zalega już od głębokości około $11 \mathrm{~m}$. Najwyższą temperaturę warstw powierzchniowych w lipcu odnotowano w 2014 roku. W warstwach powierzchniowych całego jeziora, (1m pod powierzchnią), temperatura wody przekroczyła $24^{\circ} \mathrm{C}$.

Przyczyną łagodnego, ale wyraźnego spadku temperatury $\mathrm{w}$ warstwie epilimnionu $\mathrm{w}$ trzech punktach pomiarowych może być względnie długotrwały, bezwietrzny okres, niesprzyjający mieszaniu wody jeziora. Wyniki pomiarów zawartości tlenu rozpuszczonego w wodzie w lipcu świadczą o jego
At the 1st measurement point (southern basin) the water layer to a depth of $5 \mathrm{~m}$ reached a temperature of $23^{\circ} \mathrm{C}$. In 2015 and 2016, the thickness of this layer is comparable, although the temperature is lower. Below this layer, the temperature of the entire lake in this period sharply drops, and at a depth of 5 to 7 meters it decreases by a few degrees, even in a much shallower $(11 \mathrm{~m})$ northern basin.

In the cool layer from depths of $15 \mathrm{~m}$ to the bottom, the oxygen conditions deteriorate, especially in 2015 , where in June a lack of it was noted from a depth of $18 \mathrm{~m}$ (1st and 2nd measurement point). Poor oxygen saturation (below $5 \mathrm{mg} / \mathrm{dm} 3$ ) was also characteristic of surface layers within the whole lake in June, as well as in July and August 2014. In the same months in 2015 and 2016 in the surface layer, the dissolved oxygen concentration in water was almost twice as high (compared to 2014).

Thermal profiles prepared on the basis of measurements carried out in July 2015 and 2016 already have a typical shape for the summer stagnation period of lakes in the temperate climate zone. The thermal leap zone separates the relatively warm epilimnion (about $23^{\circ} \mathrm{C}$ ) over a column of more than 8 meters (point 2 ) from the hypolimnion, which in 2016 is already about $11 \mathrm{~m}$ deep. The highest temperature of surface layers in July was recorded in 2014. In the surface layers of the whole lake ( $1 \mathrm{~m}$ below the surface), the water temperature exceeded $24^{\circ} \mathrm{C}$.

The reason for the mild but distinct temperature drop in the epilimnion layer at the three measurement points can be a relatively long-lasting, windless period, which is not conducive to the mixing of lake water. The results of the measurements of the dissolved oxygen content in water during the month of July indicate its deficit already below the depth of $8 \mathrm{~m}$ (even at point 3 ), 
deficycie już poniżej głębokości 8 m (nawet w punkcie 3), a warunki beztlenowe $\mathrm{w}$ hypolimnionie $\mathrm{w}$ trzech kolejnych latach (w punkcie 1 i 2) stwierdzono poniżej 16 m głębokości. W roku 2014 brak tlenu rozpuszczonego w wodzie stwierdzono już na głębokości $7 \mathrm{~m}$.

W szczycie stagnacji letniej przypadającym na miesiąc sierpień warunki termiczno-tlenowe były porównywalne do obserwowanych w lipcu. Jedynie w sierpniu roku 2014 temperatura epilimnionu (w stosunku do pomiarów z lipca) wyraźnie spadła z $24^{\circ} \mathrm{C}$ do $18^{\circ} \mathrm{C}$. Przyczyną tak gwałtownego spadku temperatury w miesiacach letnich może być intensywne przemieszanie ciepłych, przypowierzchniowych warstw $\mathrm{z}$ chłodniejszymi, zalegającymi w strefie metalimnionu. Krzywe profili termiczno-tlenowych wykonanych na podstawie przeprowadzonych pomiarów ilustrują powyższą interpretację uzyskanych wyników.

\section{WNIOSKI}

1. Dominującą część wzajemnej zmienności zawartości tlenu rozpuszczonego i temperatury wyjaśnia liniowa korelacja pomiędzy tymi wielkościami. Jej miara, czyli kwadrat współczynnika korelacji, osiąga wartości przekraczające nawet 99\% i nie spada poniżej $70 \%$. Potwierdza to trafność punktu 1 hipotezy badawczej.

2. Na podstawie pomiarów temperatury potwierdzono przyjętą hipotezę o zróżnicowanej miąższości warstw stratyfikacyjnych w trzech głównych basenach Jeziora Charzykowskiego. Prawdopodobnymi przyczynami tych różnic są: odmienna budowa morfometryczna poszczególnych basenów jeziora i wpływ warunków klimatycznych, w tym szczególnie dominujący kierunek wiatrów.

3. Deficyty tlenu w warstwach naddennych zaobserwowano już od czerwca, a w kolejnych miesiącach strefa beztlenowa powiększała się, by w miesiącu sierpniu, (szczyt stagnacji letniej), osiągnąć granicę metalimnionu. Dotyczy to basenów południowego i środkowego (punkty 1 i 2), a w basenie północnym (punkt 3) pomimo niewielkiej, maksymalnej głębokości w miesiącach lipcu i sierpniu zaobserwowano wyraźne deficyty tlenu rozpuszczonego już poniżej głębokości 8 metrów. and anaerobic conditions in hypolimnion in three subsequent years (in points 1 and 2) were observed below the depth of $16 \mathrm{~m}$. In 2014, the lack of dissolved oxygen in water was already noted at a depth of $7 \mathrm{~m}$.

At the peak of summer stagnation falling in August, the thermal-oxygen conditions were comparable to those observed in July. Only in August 2014, the temperature of the epilimnion (compared to the measurements from July) clearly decreased from $24^{\circ} \mathrm{C}$ to $18^{\circ} \mathrm{C}$. The reason for such a rapid drop in temperature in the summer months can be the intense mixing of warm near-surface layers with colder ones in the metalimnion zone. The curves of thermal-oxygen profiles, prepared on the basis of the measurements carried out, illustrate the above interpretation of the obtained results.

\section{Conclusions}

1. The dominant part of mutual variability of the dissolved oxygen content and temperature is explained by the linear correlation between these values. Its measure, i.e. the square of the correlation coefficient, reaches values exceeding even $99 \%$ and does not fall below $70 \%$. This confirms the accuracy of point 1 of the research hypothesis.

2. Based on the temperature measurements, the accepted hypothesis concerning the varying thickness of the stratification layers in the three main basins of Lake Charzykowskie was confirmed. The most probable reasons for these differences are: the different morphometric structure of particular lake basins and the effect of climatic conditions, including the particularly dominant wind direction.

3. Oxygen deficits in the bottom layers were observed since June, and in the following months the anaerobic zone increased to reach the metalimnion limit in August (peak of summer stagnation). This applies to the southern and middle basins (points 1 and 2), and in the northern basin (point 3), despite the small maximum depth in July and August, clear deficits in dissolved oxygen were observed already below the depth of 8 meters.

\section{REFERENCES}

1. Water Framework Directive

2. Regulation of the Minister of the Environment of July 21, 2016 on the method of classification of the state of surface water bodies and environmental quality standards for priority substances:

3. Kudelska D, Jabłoński J, Zakrzewska E. Methodology for the measurement and assessment of the cleanliness of lakes - guidelines, Ministerstwo Administracji, Gospodarki Terenowej i Ochrony Środowiska. Warsaw; 1975: p. 59;

4. Kudelska D, Cydzik D, Soszka H. Implementation instructions for the system of evaluation of the quality of lakes. Instytut Kształtowania Środowiska, Zakład Użytkowania Wód; Warsaw: 1980;

5. Kudelska D, Cydzik D, Soszka H. Lake quality evaluation system. Instytut Kształtowania Środowiska; Warsaw: 1983: p. 44;

6. Kudelska D, Cydzik D, Soszka H. 1992, Guidelines for the basic monitoring of lakes, PIOŚ, Warsaw, $41 \mathrm{~s}$.

7. Kudelska D, Cydzik D, Soszka H. 1994, Guidelines for the basic monitoring of lakes, PIOŚ, Warsaw.;

8. Choiński A; Lakes of the globe; Publ. PWN; 2000 Warsaw;

9. Lampert W, Sommer U; Ecology of inland waters; Publ. PWN; 1996 Warsaw;

10. Skowron R., 2008, Water thermal conditions during winter stagnation in the selected lakes in Poland, Limnological Review, 8 (3), 119-128;

11. Lange W, 1985, Thermical regimes of Cassubian Lake District, Zeszyty Naukowe BiNoZ UG, Geografia, Gdańsk, 13, 57-77.];

12. Skowron R, 2011, The differentiation and the changeability of chosen of elements the thermal regime of water in lakes on Polish Lowland, Wydawnictwo Uniwersytetu M. Kopernika, Toruń, p. 345; 
13. Skowron R, 2007, The thermocline layer in the thermal water structure of selected Polish lakes, Limnological Review 7 (3), $161-169$

14. Jańczak J, Maślanka W, 2006, Cases of occurrence of secondary metalimnia in some lakes of the Ełk Lakeland, Limnological Review, 6 , 123-128;

15. Maślanka W, Nowiński K, 2006, Diversity of development of summer thermocline layer in Lake Upper Raduńskie, Limnological Review, 6 , 201-206.];

16. Sobolewski W, Borowiak D,Borowiak M,Skowron R, 2014, Database of Polish lakes and its use in limnological studies. Uniwersytet Marii Curie-Skłodowskiej Wydział Nauk o Ziemi i Gospodarki Przestrzennej. PICADOR Komunikacja Graficzna S.c. Lublin;

17. Kajak Z; Hydrobiology-limnology. The ecosystems of inland waters; Publ. PWN; 1998 Warsaw;

18. Oleksowicz A, (1981) Assessment of the surface water quality in Lake Charzykowskie based on phytoplankton analysis. Zakład Kształtowania i Ochrony Środowiska. ATR w Bydgoszczy;

19. Wiśniewska M, (1994) Phytoplankton dynamics in Lake Charzykowskie in 1987-1990. Wydawnictwo UAM Poznań;

20. Wiśniewska M., (1996) Changes In the phytoplankton of Lake Charzykowskie In relation to the environmental factors. [in:] BoryTucholskie - Biosphere Conservation. University of Łódz

21. Wiśniewska M., Luścińska M., (2012) Long-term changes in the phytoplankton of Lake Charzykowskie. Oceanological and Hydrobiological Studies. International Journal of Oceanography and Hydrobiology. Volume 41, Issue3;

22. Stangenberg M., et al., 1950. Morphometry and chemical composition of water in Lake Charzykowo. Lake Charzykowo I. Państwowe Wydawnictwo Rolnicze i Leśne. Warsaw;

23. Solski A. 1964. Limnological profile of Lake Charzykowskie and Lake Wdzydze. Polskie Archiwum Hydrobiologiczne, TOM XII (XXV) No. 2.

24. Szulkowska-Wojaczek E., 1978. Eutrophication of lakes and indicators of its progress (30-year impact of waste water in the town of Chojnice on the pollution of Lake Charzykowo and the eutrophication progress. Zeszyty Naukowe Akademii Rolniczej we Wrocławiu Nr 14. Wrocław;

25. Cieściński J. Ciechalski J., Borsuk S. Dabkowski R. Chodakowski K. Wiśniewska M. Evaluation of purity of 25 chosen lakes of the Zaborski Landscape Park on the basis of Physico-chemicalparameters". Wydawnictwo Uniwersytetu Łódzkiego. Łódź 1996;

26. Nowicka B., Nadolna A. Goszczyński J., Bojakowska I., Gliwicz T. Charzykowskie Lake, First report, Influence of stressors of Charzykowskie Lakes, program EULAKE, Warsaw 2011;

27. Kondracki J., 2011, Regional geopgraphy of Poland, Wyd. Nauk. PWN, Warsaw, p. 468;

prof. dr hab. Jerzy K. Garbacz

Uniwersytet Technologiczno-Przyrodniczy w Bydgoszczy,

Wydział Budownictwa, Architektury i Inżynierii Srodowiska,

Katedra Ekoinżynierii i Fizykochemii Środowiska

ul. Sucha 9, 85-789 Bydgoszcz

(52) $3408440 / 3408445$

jerzy.garbacz@utp.edu.p 